ISSN 0258-7122 (Print), 2408-8293 (Online)

Bangladesh J. Agril. Res. 41(1): 41-51, March 2016

\title{
BIOLOGY AND MANAGEMENT OF FRUIT BORER, Virachola isocrates (Fab.) INFESTING GUAVA
}

\author{
M. M. H. KHAN ${ }^{1}$
}

\begin{abstract}
Two experiments were conducted to study the biology of guava fruit borer, Virachola isocrates (Fab.) and to evaluate the effectiveness of management practices for managing fruit borer, Virachola isocrates (Fab.) in Sharupkathi variety of guava. The biology including morphometrics of guava fruit borer were studied in the laboratory of the Department of Entomology, PSTU, Dumki, Patuakhali during May to October, 2012. Results revealed that incubation period, larval period, pupal period of this borer ranged from 8-10, 17-46, 7-33 days, respectively and total life cycle was completed within 30 to 60 days. Adult longevity ranged from 4-7 days. The average length of full grown larva was $17.45 \mathrm{~mm}$, and breadth across thorax and abdomen were 3.36 and $2.80 \mathrm{~mm}$, respectively. The average length of pupa was $15.90 \mathrm{~mm}$, and breadth across thorax and abdomen were 3.68 and $2.89 \mathrm{~mm}$, respectively. The average length of adult body was $16.90 \mathrm{~mm}$, and breadth across thorax and abdomen were 3.91 and $2.94 \mathrm{~mm}$, respectively. The average length of antennae was $10.35 \mathrm{~mm}$. The mean length of pro-, meso and metathoracic legs was $7.55 \mathrm{~mm}, 8.10 \mathrm{~mm}$ and $10.45 \mathrm{~mm}$, respectively. The metathoracic leg was longer as compared to pro and mesothorarcic legs. The length of fore wing across the upper and lower margin ranged from $16.00 \mathrm{~mm}$ to $18.00 \mathrm{~mm}$ and $11.50 \mathrm{~mm}$ to $12.00 \mathrm{~mm}$, respectively. The length of hind wing across the upper and lower margin ranged from $10.00 \mathrm{~mm}$ to $11.00 \mathrm{~mm}$ and $8.00 \mathrm{~mm}$ to $9.00 \mathrm{~mm}$, respectively. The breadth of fore wing across the middle ranged from 10.50-11.00 with mean breadth of $10.78 \mathrm{~mm}$. Likewise, the breadth of hind wing across the middle ranged from 11.00-14.00 with mean breadth of $12.55 \mathrm{~mm}$. The results on the percent infestation reduction over control revealed that package with field sanitation + collection of infested fruits + application of Superior (Chlorpyrifos + Cypermethrin) $505 \mathrm{EC} @ 1 \mathrm{ml} / 1$ water, and package consisting of field sanitation + collection of infested fruits + bagging of fruits with polythene bag gave $100 \%$ control of the pest. These two packages may be used for the large scale cultivation of 'Sharupkathi' variety in Bangladesh.
\end{abstract}

Keywords: Biology, fruit borer, virachola isocrates (Fab.), guava, management.

\section{Introduction}

Guava (Psidium guajava L.) is one of the most popular and widely cultivated important fruit crops in Bangladesh. It is cultivated in 16,862 ha of land with an annual production of 80,525 metric tons in Bangladesh (Anon., 2004). It is very rich in vitamin C. Some varieties of guava such as 'Kazipiara', Kanchannagar, 'Mukundapuri' and 'Swarupkathi' grow everywhere in the country in the

${ }^{1}$ Department of Entomology, Patuakhali Science and Technology University, Dumki, Patuakhali -8602, Bangladesh. 
homestead gardens but commercially cultivated in Barisal, Sylhet, Gazipur and Chittagong regions. Alam et al. (1964) listed five different species of insect pests attacking guava in Bangladesh, but there was no report of Virachola isocrates (Fab.) as a pest of guava. Guava plants are attacked by a number of insect pests viz., fruit flies, bark eating caterpillars, whiteflies, semilooper, fruit borers, stem borers etc (Butani, 1979). Among them fruit borer, $V$. isocrates has been found to be a major limiting factor hindering safe cultivation of guava in Barisal region in recent years. This pest is also known as pomegranate butterfly and is, in fact, a polyphagous pest attacking a wide range of host plants, including guava, pomegranate, anola, apple, ber, citrus, litchi, peach, pear, sapota and tamarind (Atwal, 1976).

This borer damages the pomegranate by boring inside the developing fruit and feeding on pulp and seeds (Atwal, 1976; Butani, 1979). The infested fruits are also attacked by bacteria and fungi which cause the fruits to rot. The affected fruits ultimately fall off and give an offensive smell (Atwal, 1976). The extent of damage in fruit was 40-70 \% and 50-90 \% in India as reported by Bose (1985) and Ramkrishna Ayyar (1984), respectively. The infestation by fruit borer began at the marble stage of guava and the peak infestation was recorded in mid August to September in varieties 'Kazipiara', 'Kanchannagar', 'Mukundapuri' and 'Swarupkathi' (Biswas et al., 1995). Bagging of fruits was very effective means for controlling fruit borer infestation (Atwal, 1976; Nayar and Ananthakrishnan, 1976; Ramkrishna Ayyar, 1984; Biswas et al., 1996). Shukla and Prasad (1983) reported that the most effective treatments were bagging fruits with polythene or muslin bag. Maniruzzaman (1981) suggested control of this pest by spraying Diazinon or Malathion when the fruits were young. Kakar et al. (1987) suggested the use of Cypermethrin (@150 g a i/ha) and Deltamethrin (@7.5 g a i/ha) for effective and profitable control of fruit borer. Khan (2010) reported that bagging fruits with transparent perforated polythene bag and the similar bag impregnated with Decis $2.5 \mathrm{EC} @ 1 \mathrm{ml} / \mathrm{l}$ of water were found effective against guava fruit borer infesting 'Kazipiara' variety in small scale cultivation. He also suggested that three sprays of Decis@ @ $0.25 \mathrm{ml} / \mathrm{l}$ of water at 7 days interval could be good treatment in controlling this pest in large scale cultivation. Biswas et al. (1996) reported that the infestation of fruit borer was reduced $39.06 \%$ to $48.53 \%$ over control by the application of Ripcord, Diazinon and Malathion. In Bangladesh, there are no suggested and recommended control measures for the management of this fruit borer. Therefore, the present research work was undertaken to study the detailed biology of fruit borer and to evaluate the effectiveness of different IPM packages for controlling fruit borer in guava.

\section{Materials and Method}

\section{Biology of fruit borer infesting guava}

The study on the biology of fruit borer was conducted in the laboratory of the Department of Entomology, Patuakhali Science and Technology University, 
Dumki, Patuakhali from April to August, 2012. Infested fruits of guava were collected from farmers' orchard and PSTU campus. The collected specimens were suitably processed and labeled for further studies. The collected fruits were kept in plastic pot for insect rearing. Ten plastic pots and each pot containing five fruits were maintained. To study the larval and pupal development, observation was made on larval instars and pupation. The infested guava of different aged were cut and opened to observe larval instars and pupal stages of this borer. The duration of larval, pupal and adult stages were recorded at each date of observation. The length and breadth of different stages of this borer was also measured and recorded. The mean temperature and relative humidity during the period of study were also recorded.

\section{Effectiveness of different IPM packages in suppressing fruit borer}

Field trial was carried out to evaluate the effectiveness of different IPM packages against fruit borer at PSTU campus and farmer's orchard during May to October, 2012. Swarupkathi variety of guava was used for the study. IPM packages were: $\mathrm{P}_{1}=$ field sanitation + collection of infested fruits + application of Chita (Chlorpyrifos) $48 \mathrm{EC} @ 1 \mathrm{ml} / \mathrm{l}$ water, $\mathrm{P}_{2}=$ field sanitation + collection of infested fruits + application of Fighter (Cypermethrin) 10 EC @ $1 \mathrm{ml} / 1$ water, $\mathrm{P}_{3}=$ field sanitation + collection of infested fruits + application of Superior (Chlorpyrifos + Cypermethrin) $505 \mathrm{EC} @ 1 \mathrm{ml} / 1$ water, $\mathrm{P}_{4}=$ field sanitation + collection of infested fruits + bagging of fruits with polythene bag and an untreated control. The experiment was laid out in RCBD with 4 replications. A total of 20 branches were randomly selected for the study. The spraying was done as a full cover (covering leaves, fruits, branches and the trunk of a tree) at the time of application.

\section{Data collection}

Fruits of all treatments were harvested, bagged and labeled carefully for each plant and transported to the laboratory where the fruits were checked thoroughly for detecting the sign of the fruit borer infestation. The visible damage symptom in an infested fruit was the presence of excreta of the larva which coming out of the entry hole. Even single entry hole on the fruit was considered as an infested fruit. Data on the number of fruit examined, the number and weight of healthy and infested fruits were recorded for each treatment and for each plant. The percent of fruit infestation (by number and weight) in each treatment was calculated from the number and weight of the infested fruits. The percent infestation reduction over untreated control was also calculated.

The statistical analysis was performed by using MSTAT-C program. The analysis of variance (ANOVA) of the results on various insect pests was done after square root transformation. Test of significance was performed by F-test. Means were separated by Least Significant Difference (LSD) test. 


\section{Results and Discussion}

\section{Biology of guava fruit borer}

\section{Appearance}

Adult male butterfly is violet-blue and the female is violet brown, female with $\mathrm{V}$ shaped patch on forewing. Hind wing bears spots (Fig. 1-3). Larvae of different instars were dark brown (Fig. 4-6). The full-grown larvae are dark brown with short hair and white patches all over the body (Fig. 7).

\section{Developmental period and adult longevity of guava fruit borer}

Eggs are laid singly on tender leaves, stalks and flower buds. Incubation period lasts for 8-10 days with average period of 8.8 days. Larval period lasts for 17-46 days with mean duration of 31.4 days. Pupation occurs either inside the damaged fruits or on the stalk holding it (Fig. 8). Pupal period lasts for 7-33 days with mean duration of 16 days. Total life cycle is completed within 30 to 60 days with average duration of 46.5 days. Adult longevity ranged from 4-7 days with average 5.7 days (Table 1). No published research report regarding this is available to compare the findings of the present study.

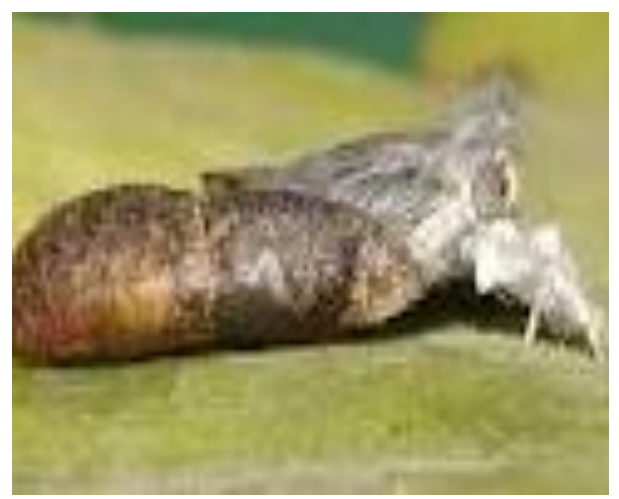

Fig. 1. Adult emergence from pupa

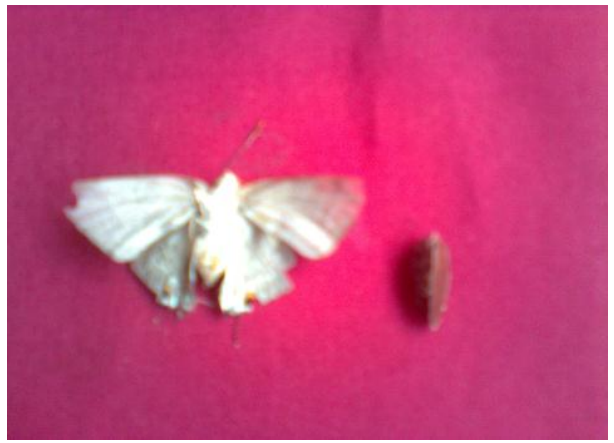

Fig. 3. Adult butterfly (ventral view)

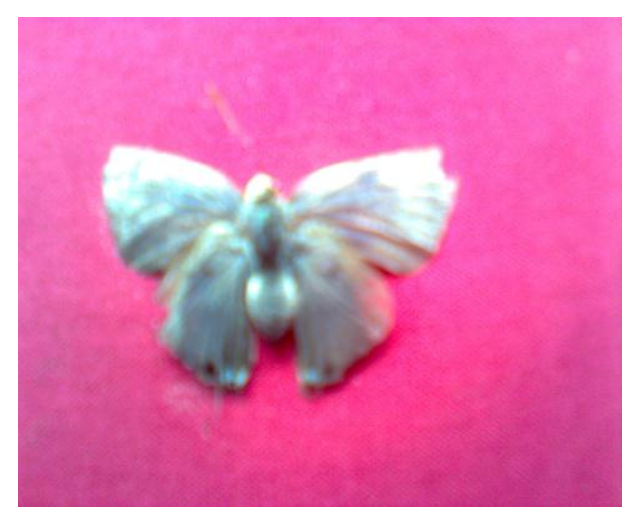

Fig. 2. Adult butterfly (dorsal view)

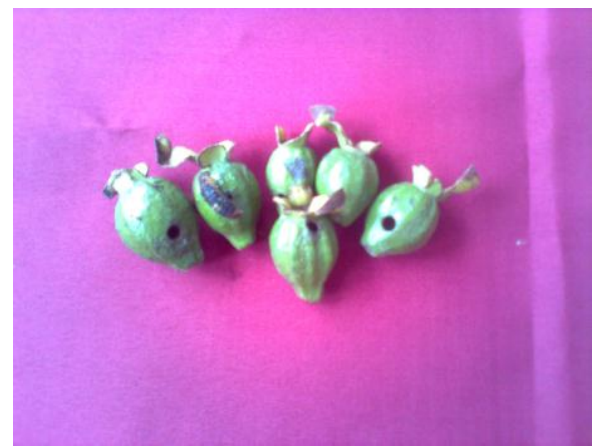

Fig. 4. First instar larva 


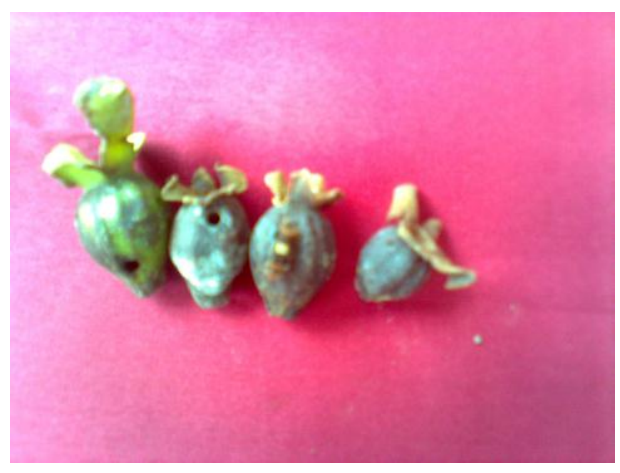

Fig. 5. Second instar larva

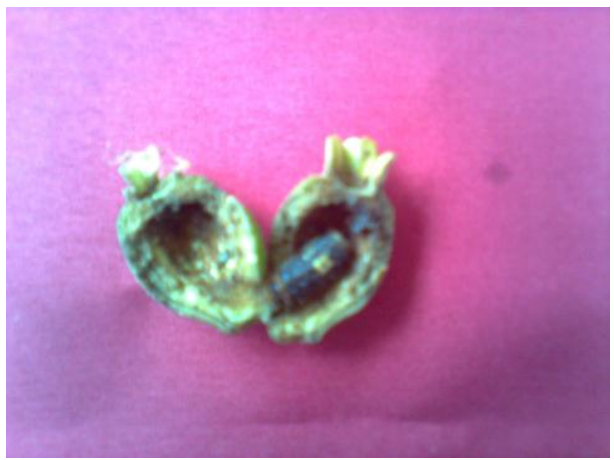

Fig. 7. Fourth instar larva

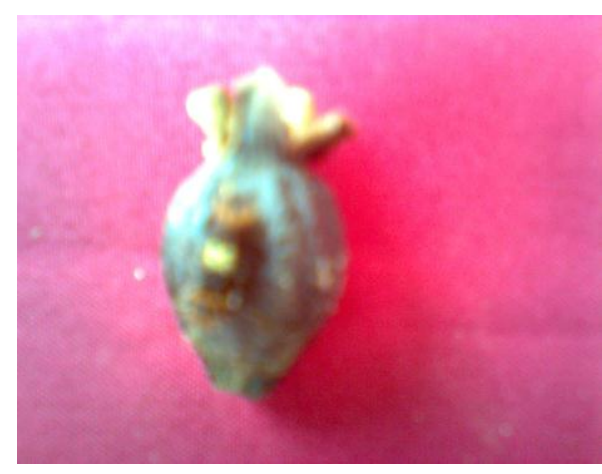

Fig. 6. Third instar larva

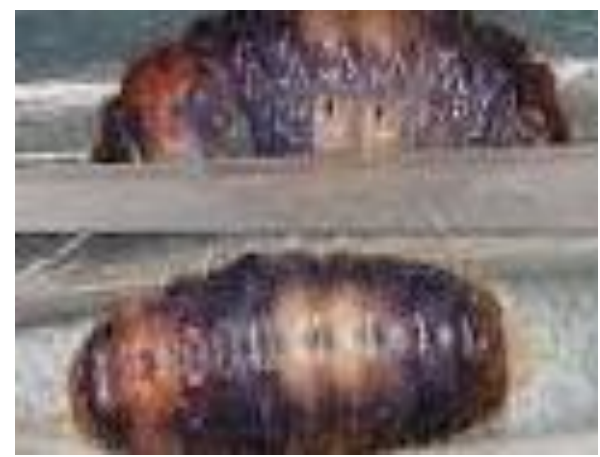

Fig. 8. Pupa (enlarged form)

Table 1. Developmental period and adult longevity of guava fruit borer, Virachola isocrates (Fab.) grown on Sharupkathi variety

\begin{tabular}{l|c|c}
\hline \multirow{2}{*}{\multicolumn{1}{c}{ Developmental stages }} & \multicolumn{2}{c}{ Duration (Days) } \\
\cline { 2 - 3 } & Range & Mean \pm SE \\
\hline Incubation period & $8-10$ & $8.80 \pm 0.24$ \\
Larval period & $17-46$ & $31.40 \pm 3.09$ \\
Pupal period & $7-33$ & $16.00 \pm 2.71$ \\
Total life cycle & $30-60$ & $46.50 \pm 2.91$ \\
Adult longevity & $4-7$ & $5.70 \pm 0.35$ \\
\hline
\end{tabular}

Values are averages of 10 observations. $\mathrm{SE}=$ Standard Error.

\section{Nature of damage}

The larvae bored into the guava fruits soon after hatching. Once inside the fruit, larvae (approx $2 \mathrm{~cm}$ length) feed on the flesh and seeds. The bored hole was plugged by the last abdominal segment of the larva (Plate 9 A-C). When fully grown, the larva came out of boring through the hard shell and spined a web, which tied the fruit or stalked of the main branch. 


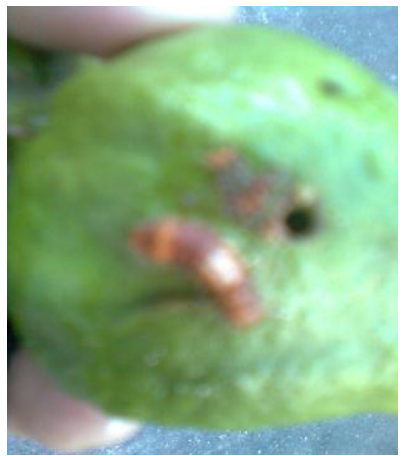

A

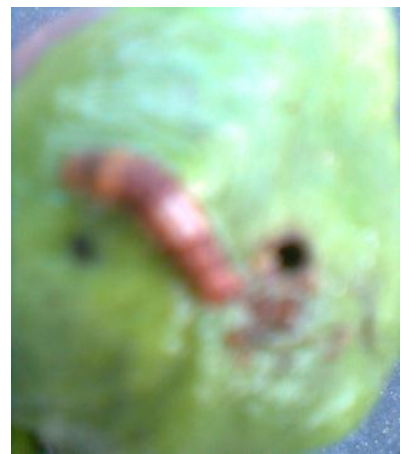

B

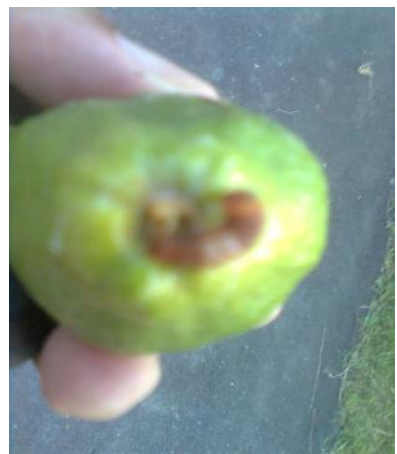

C

Fig. 9 (A-C). Damaged and bored guava fruit with larvae and excreta.

\section{Damage symptoms}

Offensive smell emitted and excreta of caterpillars came toward the entry holes and it stucks around the holes. The infested fruits rotted and dropped off. The holes ultimately exposed and act predisposing factor to diseases, and typically rotten on the tree (Fig. 10-12).

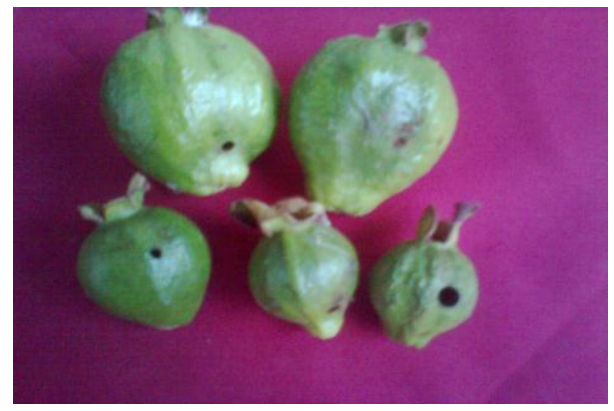

Fig. 10. Infested fruits of different size

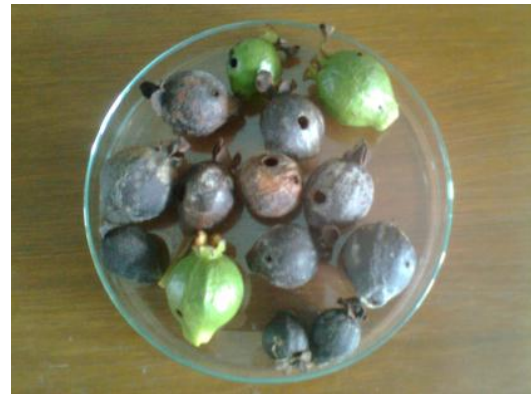

Fig. 11. Small size infested and rotten fruits

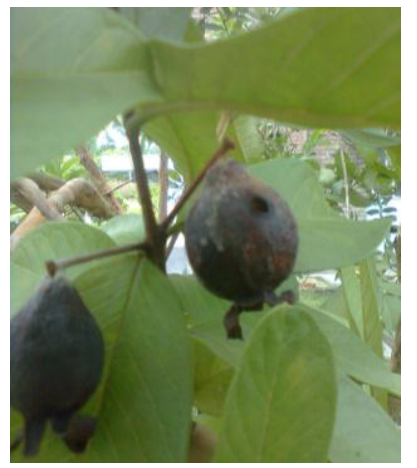

Fig. 12. Guava tree bearing bored and rot fruits 
Table 2. Morphometrics of life stages and appendages of guava fruit borer, Virachola isocrates

\begin{tabular}{|c|c|c|}
\hline Life stages and appendages & Range (mm) & Mean \pm SE $(\mathrm{mm})$ \\
\hline \multicolumn{3}{|l|}{ Full grown larva } \\
\hline Length & $16.00-20.00$ & $17.45 \pm 0.39$ \\
\hline \multicolumn{3}{|l|}{ Breadth } \\
\hline -Across thorax & $3.00-3.80$ & $3.36 \pm 0.08$ \\
\hline -Across abdomen & $2.70-2.90$ & $2.80 \pm 0.02$ \\
\hline \multicolumn{3}{|l|}{ Pupa } \\
\hline Length & $15.00-17.00$ & $15.90 \pm 0.23$ \\
\hline \multicolumn{3}{|l|}{ Breadth } \\
\hline -Across thorax & $3.50-4.00$ & $3.68 \pm 0.06$ \\
\hline -Across abdomen & $2.80-3.00$ & $2.89 \pm 0.03$ \\
\hline \multicolumn{3}{|l|}{ Adult } \\
\hline \multicolumn{3}{|l|}{ Body } \\
\hline Length & $16.50-17.50$ & $16.90 \pm 0.12$ \\
\hline \multicolumn{3}{|l|}{ Breadth } \\
\hline -Across thorax & $3.80-4.00$ & $3.91 \pm 0.03$ \\
\hline -Across abdomen & $2.80-3.00$ & $2.94 \pm 0.03$ \\
\hline \multicolumn{3}{|l|}{ Antenna } \\
\hline Length & $9.00-11.00$ & $10.35 \pm 0.21$ \\
\hline \multicolumn{3}{|l|}{ Leg length } \\
\hline Prothoracic & $7.00-8.00$ & $7.55 \pm 0.13$ \\
\hline Mesothoracic & $7.50-9.00$ & $8.10 \pm 0.17$ \\
\hline Metathoracic & $9.50-11.50$ & $10.45 \pm 0.21$ \\
\hline \multicolumn{3}{|l|}{ Wing length } \\
\hline \multicolumn{3}{|l|}{ Fore wing } \\
\hline - Across upper margin & $16.00-18.00$ & $17.05 \pm 0.22$ \\
\hline - Across lower margin & $11.50-12.00$ & $11.85 \pm 0.07$ \\
\hline \multicolumn{3}{|l|}{ Hind wing } \\
\hline - Across upper margin & $10.00-11.00$ & $10.55 \pm 0.13$ \\
\hline - Across lower margin & $8.00-9.00$ & $8.58 \pm 0.11$ \\
\hline \multicolumn{3}{|l|}{ Wing Breadth } \\
\hline Fore wing -Across middle & $10.50-11.00$ & $10.78 \pm 0.06$ \\
\hline Hind wing-Across middle & $11.00-14.00$ & $12.55 \pm 0.34$ \\
\hline
\end{tabular}

Values are averages of 10 observations. SE= Standard Error. 


\section{Morphometrics of larva, pupa, adult and appendages}

The results on the morphometrical aspect of guava fruit borer, Virachola isocrates are presented in Table 2 and Fig. 13-16. The full-grown larvae were dark brown with short hair and white patches all over the body. The length of full grown larva ranged from $16.00 \mathrm{~mm}$ to $20.00 \mathrm{~mm}$. The average length of full grown larva was $17.45 \mathrm{~mm}$ and breadth across thorax and abdomen were 3.36 and $2.80 \mathrm{~mm}$, respectively (Table 2). The larva pupates either inside the damaged fruits or on the stalk holding it. The average length of pupa was $15.90 \mathrm{~mm}$ and breadth across thorax and abdomen were 3.68 and $2.89 \mathrm{~mm}$, respectively (Table 2). Adult Virachola isocrates was bluish brown and the average length of body was 16.90 $\mathrm{mm}$, and breadth across thorax and abdomen were 3.91 and $2.94 \mathrm{~mm}$, respectively. Antennae were very long and the average length of antennae was $10.35 \mathrm{~mm}$ (Table 2). The mean length of pro, meso and metathoracic legs was $7.55 \mathrm{~mm}, 8.10 \mathrm{~mm}$ and $10.45 \mathrm{~mm}$, respectively. The metathoracic leg was longer as compared to pro and mesothorarcic legs. The length of fore wing across the upper and lower margin ranged from $16.00 \mathrm{~mm}$ to $18.00 \mathrm{~mm}$ and $11.50 \mathrm{~mm}$ to $12.00 \mathrm{~mm}$, respectively with average length $17.05 \mathrm{~mm}$ and $11.85 \mathrm{~mm}$, respectively. Similarly, the length of hind wing across the upper and lower margin ranged from $10.00 \mathrm{~mm}$ to $11.00 \mathrm{~mm}$ and $8.00 \mathrm{~mm}$ to $9.00 \mathrm{~mm}$, respectively with average length $10.55 \mathrm{~mm}$ and $8.58 \mathrm{~mm}$, respectively. The breadth of fore wing across the middle ranged from 10.50-11.00 with mean breadth of $10.78 \mathrm{~mm}$. Likewise, the breadth of fore wing across the middle ranged from 11.00-14.00 with mean breadth of $12.55 \mathrm{~mm}$ (Table 2). No published research report regarding this is available to compare the findings of the present study.

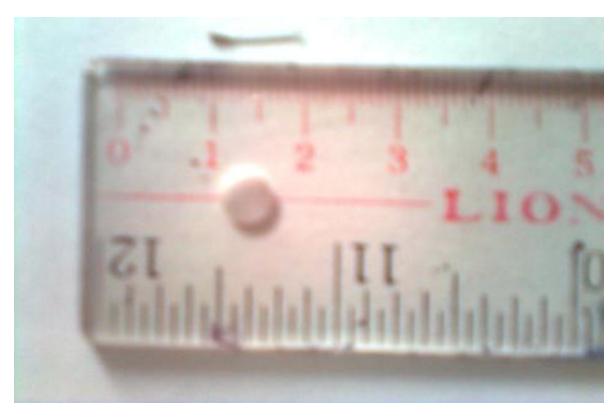

Fig. 13. Antenna

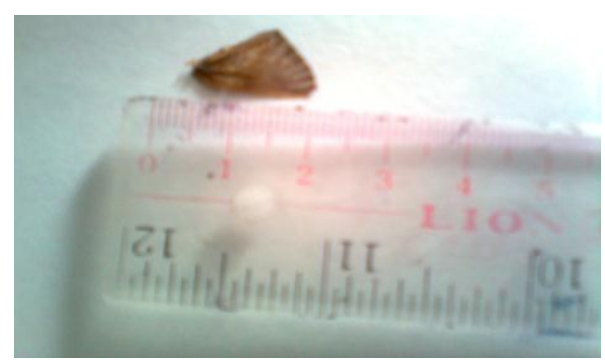

Fig. 15. Fore wing

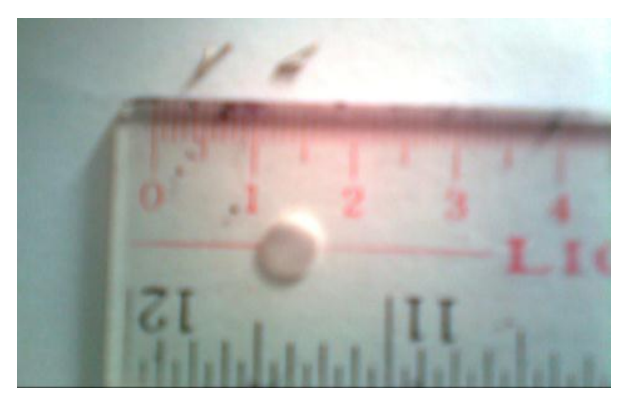

Fig. 14. Leg

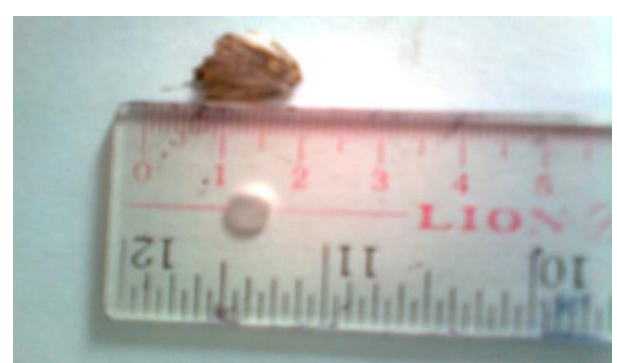

Fig. 16. Hind wing 


\section{Management of guava fruit borer}

The effectiveness of different IPM packages on the infestation of guava fruit borer is presented in Table 3. The number of infested fruits ranged from $4.13\left(\mathrm{P}_{1}\right)$ to 9.69 (Untreated control). The infestation was not observed in the packages $\mathrm{P}_{3}$ and $\mathrm{P}_{4}$. Significantly the highest number (9.69) of infested fruits was observed in untreated control and lowest (4.13) in $\mathrm{P}_{1}$ which was statistically similar to that of $\mathrm{P}_{2}$. The weight of infested fruits varied from $102.76 \mathrm{~g}\left(\mathrm{P}_{1}\right)$ to $203.24 \mathrm{~g}$ for (Untreated control). Statistically significant difference was observed among different packages with respect to the percentage of fruit infestation (by number and weight) due to the damage caused by the guava fruit borer. The highest percentage of infested fruits (by number) was in untreated control $(24.22 \%)$. Likewise, the same trend was also found on the percentage of infested fruits by weight. Percentage of infestation was nil in the treatments $\mathrm{P}_{3}$ and $\mathrm{P}_{4}$ and the highest percentage of infestation (by weight) was also observed in the untreated control $(41.03 \%)$.

Table 3. Effectiveness of different IPM packages on the infestation of fruit borer, Virachola isocrates (Fab.) in guava

\begin{tabular}{c|c|c|c|c|c|c|c}
\hline Treatment & $\begin{array}{c}\text { Total } \\
\text { no. of } \\
\text { fruits } \\
\text { studied }\end{array}$ & $\begin{array}{c}\text { No. of } \\
\text { infested } \\
\text { fruits }\end{array}$ & $\begin{array}{c}\text { Weight } \\
\text { of } \\
\text { healthy } \\
\text { fruits } \\
(\mathrm{g})\end{array}$ & $\begin{array}{c}\text { Weight } \\
\text { of } \\
\text { infested } \\
\text { fruits (g) }\end{array}$ & $\begin{array}{c}\% \text { infested } \\
\text { fruits } \\
\text { (by } \\
\text { number) }\end{array}$ & $\begin{array}{c}\text { \% infested } \\
\text { fruits } \\
\text { (by weight) }\end{array}$ & $\begin{array}{c}\% \text { infestation } \\
\text { reduction } \\
\text { over control } \\
\text { (by number) }\end{array}$ \\
\hline $\mathrm{P}_{1}$ & 40 & $4.13 \mathrm{~b}$ & 486.00 & $102.76 \mathrm{~b}$ & $\begin{array}{c}10.33 \mathrm{~b} \\
(3.29)\end{array}$ & $\begin{array}{c}21.14 \mathrm{~b} \\
(4.65)\end{array}$ & 48.48 \\
$\mathrm{P}_{2}$ & 40 & $5.11 \mathrm{~b}$ & 486.12 & $107.00 \mathrm{~b}$ & $\begin{array}{c}12.78 \mathrm{~b} \\
(3.64)\end{array}$ & $\begin{array}{c}22.01 \mathrm{~b} \\
(4.74)\end{array}$ & 46.36 \\
$\mathrm{P}_{3}$ & 40 & $0.00 \mathrm{c}$ & 412.76 & $0.00 \mathrm{c}$ & $\begin{array}{c}0.00 \mathrm{c} \\
(0.71)\end{array}$ & $\begin{array}{c}0.00 \mathrm{c} \\
(0.71)\end{array}$ & 100.00 \\
$\mathrm{P}_{4}$ & 40 & $0.00 \mathrm{c}$ & 413.04 & $0.00 \mathrm{c}$ & $0.00 \mathrm{c}$ & $0.00 \mathrm{c}$ & 100.00 \\
& & & & & $(0.71)$ & $(0.71)$ & \\
Untreated & 40 & $9.69 \mathrm{a}$ & 495.28 & $203.24 \mathrm{a}$ & $24.22 \mathrm{a}$ & $41.03 \mathrm{a}$ & - \\
control & & & & $(4.97)$ & $(6.44)$ & \\
\hline F-value & & 7.46 & & 8.43 & 16.39 & 13.75 & \\
\hline CV (\%) & 8.53 & & 9.54 & 11.23 & 10.39 & \\
\hline LSD (0.01) & 1.36 & & 0.75 & 0.80 & 0.45 & \\
\hline
\end{tabular}

Figures within parentheses are the transformed values based on square root $(\sqrt{x}+0.5)$ transformation.

Values are averages of 4 replications. 
IPM packages were: $\mathrm{P}_{1}=$ field sanitation + collection of infested fruits + application of Chita (Chlorpyrifos) $48 \mathrm{EC} @ 1 \mathrm{ml} / \mathrm{l}$ water, $\mathrm{P}_{2}=$ field sanitation + collection of infested fruits + application of Fighter (Cypermethrin) 10 EC @ 1 $\mathrm{ml} / 1$ water, $\mathrm{P}_{3}=$ field sanitation + collection of infested fruits application of Superior (Chlorpyrifos + Cypermethrin) 505 EC @ $1 \mathrm{ml} / 1$ water, $\mathrm{P}_{4}=$ field sanitation + collection of infested fruits + bagging of fruits with polythene bag and an untreated control.

The results on the per cent infestation reduction over control revealed that field sanitation + collection of infested fruits + application of Superior (Chlorpyrifos + Cypermethrin) 505 EC @ $1 \mathrm{ml} / 1$ water $\left(\mathrm{P}_{3}\right)$, and field sanitation + collection of infested fruits + bagging of fruits with polythene bag $\left(\mathrm{P}_{4}\right)$ gave $100 \%$ control of the pest followed by field sanitation + collection of infested fruits + application of Chita (Chlorpyrifos) 48 EC @ $1 \mathrm{ml} / 1$ water $\left(\mathrm{P}_{1}\right)$ and field sanitation + collection of infested fruits + application of Fighter (Cypermethrin) 10 EC @ 1 $\mathrm{ml} / 1$ water $\left(\mathrm{P}_{2}\right)$ resulting in $48.48 \%$ and $46.36 \%$ reduction, respectively of infestation over control (Table 3). These findings were in agreement with the observations of Biswas et al. (1996) who found that the infestation of fruit borer was reduced $39.06 \%$ to $48.53 \%$ over control by the application of Ripcord, Diazinon and Malathion, and Khan (2010) found that three spraying of Decis @ $0.25 \mathrm{ml} / \mathrm{l}$ of water was effective against fruit borer of 'Kazipiara' variety of guava in large scale cultivation in Bangladesh. Atwal (1976) and Nayar and Ananthakrishnan (1976) reported that bagging an effective means of controlling fruit borer infestation. Shukla and Prasad (1983) reported that the most effective treatments were bagging fruits with polyethene or muslin. Similar observations were made by Ramkrishna Ayyar (1984).

The study had provided information on biology of guava fruit borer and effectiveness of IPM packages for their suppression. From the above mentioned results it may be concluded that field sanitation + collection of infested fruits + bagging of fruits with polythene bag could be an effective and profitable IPM package for the production of Sharupkathi variety of guava in small scale cultivation. But the IPM package consisting of field sanitation + collection of infested fruits + application of Superior (Chlorpyrifos + Cypermethrin) 505 EC @ $1 \mathrm{ml} / 1$ water may be practiced for large scale cultivation of Sharupkathi guava variety in Bangladesh.

\section{Acknowledgement}

Author is grateful to the authority of PSTU for financial assistance to accomplish this research work and also to Head, Department of Entomology, PSTU for providing laboratory facilities during the study period. 


\section{References}

Alam, M. Z., A. Ahmad, S. Alam and M. A. Islam. 1964. A Review of Research, Division of Entomology (1947-64). Agricultural Information Service, 3, R. K. Mission Road, Dhaka. 272 p.

Anonymous. 2004. Year Book of Agricultural Statistics, Bangladesh Bureau of Statistics. $381 \mathrm{p}$.

Atwal, A. S. 1976. Agricultural pests of India and South-East Asia. Kalyani Publishers, Ludhiana. 529 p.

Biswas, G. C., M. Ahmad, M. A. Karim and M. Y. Miah. 1995. Incidence of fruit borer (Virachola isocrates F.) on guava at Khagrachari Hill District. Bangladesh J. Entomol. 5 (1\&2): 33-39.

Biswas, G. C., M. A. Karim and M. Y. Miah 1996. Morphology and control of fruit borer (Virachola isocrates F.) of guava. Bangladesh J. Agric. Res. 21 (2): 294-300.

Bose, T. K. 1985. Fruits of India, tropical and sub-tropical. Naya Prokash, Calcutta, India. $637 \mathrm{p}$.

Butani, D. K. 1979. Insects and fruits. Periodical Expert Book Agency, New Delhi. 415 p.

Kakar, K. L., G. S. Gora and A. Nath. 1987. Incidence and control of pomegranate fruit borer, Virachola isocrates (Fab.). Indian J. Agril. Sci. 57 (10): 749-752.

Khan, M. M. H. 2010. Effect of bagging and insecticides in controlling fruit borer, Virachola isocrates (Fab.) of guava. Bangladesh J. Life Sci. 22 (2): 135-140.

Maniruzzaman, F. M. 1981. Plant protection in Bangladesh. Agril. Res. Inst. Dhaka. 355 p.

Nayar, K. K. and T. N. Ananthakrishnan. 1976. General and applied entomology. TataMcgraw Hill Publishing Co., New Delhi. 589 p.

Ramkrishna Ayyar, T. V. 1984. Handbook of Economic Entomology for South India. International Books and Periodical Supply Service, Karol Bagh. New Delhi. 528 p.

Shukla, R. P. and V. G. Prasad. 1983. Comparative efficacy of various treatments for controlling pomegranate fruit borer, Virachola isocrates (Fab.). Indian Inst. Hort. Res. 8 (4): 381-383. 